\title{
A new $\mathrm{X}$ linked recessive deafness syndrome with blindness, dystonia, fractures, and mental deficiency is linked to $\mathrm{Xq} 22$
}

\begin{abstract}
Lisbeth Tranebjærg, Charles Schwartz, Hans Eriksen, Sten Andreasson, Vesna Ponjavic, Arve Dahl, Roger E Stevenson, Melanie May, Fernando Arena, David Barker, Hans Hugo Elverland, Herbert Lubs
\end{abstract}

Abstract

$X$ linked recessive deafness accounts for only $1 \cdot 7 \%$ of all childhood deafness. Only $a$ few of the at least 28 different $X$ linked syndromes associated with hearing impairment have been characterised at the molecular level. In 1960, a large Norwegian family was reported with early onset progressive sensorineural deafness, which was indexed in McKusick as DFN-1, McKusick 304700. No associated symptoms were described at that time.

This family has been restudied clinically. Extensive neurological, neurophysiological, neuroradiological, and biochemical, as well as molecular techniques, have been applied to characterise the $X$ linked recessive syndrome. The family history and extensive characterisation of 16 affected males in five generations confirmed the $X$ linked recessive inheritance and the postlingual progressive nature of the sensorineural deafness. Some obligate carrier females showed signs of minor neuropathy and mild hearing impairment.

Restudy of the original DFN-1 family showed that the deafness is part of a progressive $X$ linked recessive syndrome, which includes visual disability leading to cortical blindness, dystonia, fractures, and mental deficiency. Linkage analysis indicated that the gene was linked to locus DXS101 in Xq22 with a lod score of 5.37 (zero recombination). Based on lod-1 support interval of the multipoint analysis, the gene is located in a region spanning from $5 \mathrm{cM}$ proximal to $3 \mathrm{cM}$ distal to this locus. As the proteolipid protein gene (PLP) is within this region and mutations have been shown to be associated with non-classical PMD (Pelizaeus-Merzbacher disease), such as complex $X$ linked hereditary spastic paraplegia, PLP may represent a candidate gene for this disorder.

This family represents a new syndrome (Mohr-Tranebjærg syndrome, MTS) and provides significant new information about a new $X$ linked recessive syndromic type of deafness which was previously thought to be isolated deafness.

( $($ Med Genet 1995;32:257-263)

$\mathrm{X}$ linked recessive deafness is rare, accounting for $1 \cdot 7 \%$ of all childhood deafness. ${ }^{12}$ A number of clinically recognisable $\mathrm{X}$ linked syndromes are also accompanied by deafness. ${ }^{3}$ According to Bach et $a l^{4}$ at least 28 different $\mathrm{X}$ linked disorders cause hearing impairment. However, only a few have been characterised at the molecular level. ${ }^{3}$

The classification of non-syndromic X linked deafness recognises four types of deafness: $X$ linked, early onset, progressive sensorineural (McKusick 304700, DFN-1), congenital sensorineural (McKusick 304500, DFN-2), progressive mixed deafness with perily, nphatic gusher (McKusick 304400, DFN-3), and high tone sensorineural deafness (McKusick $304600, \mathrm{DFN}-4) .^{5}$ The category of DFN-1 is based on the description of one Norwegian family reported in $1960 .^{6}$

This report presents a restudy of this Norwegian family with DFN-1.$^{6}$ The early onset, progressive sensorineural deafness was found to be associated with progressive dystonic movements, spasticity, mental deterioration, aggressive behaviour, and significant visual disability leading to blindness. The condition thus represents a previously unrecognised $\mathrm{X}$ linked recessive syndromal deafness. Furthermore, the gene for this syndrome was found to be linked to genetic markers in Xq22. This report emphasises the value of clinical restudy of previously published families. Moreover, a new classification system for deafness which includes the molecular genetic information is needed.

\section{Methods}

Information on all affected males was compiled from medical records, including successive audiological assessments. Sixteen affected males were known, of whom 10 were alive and all had clinical examinations. They ranged in age from 14 to 60 years. 


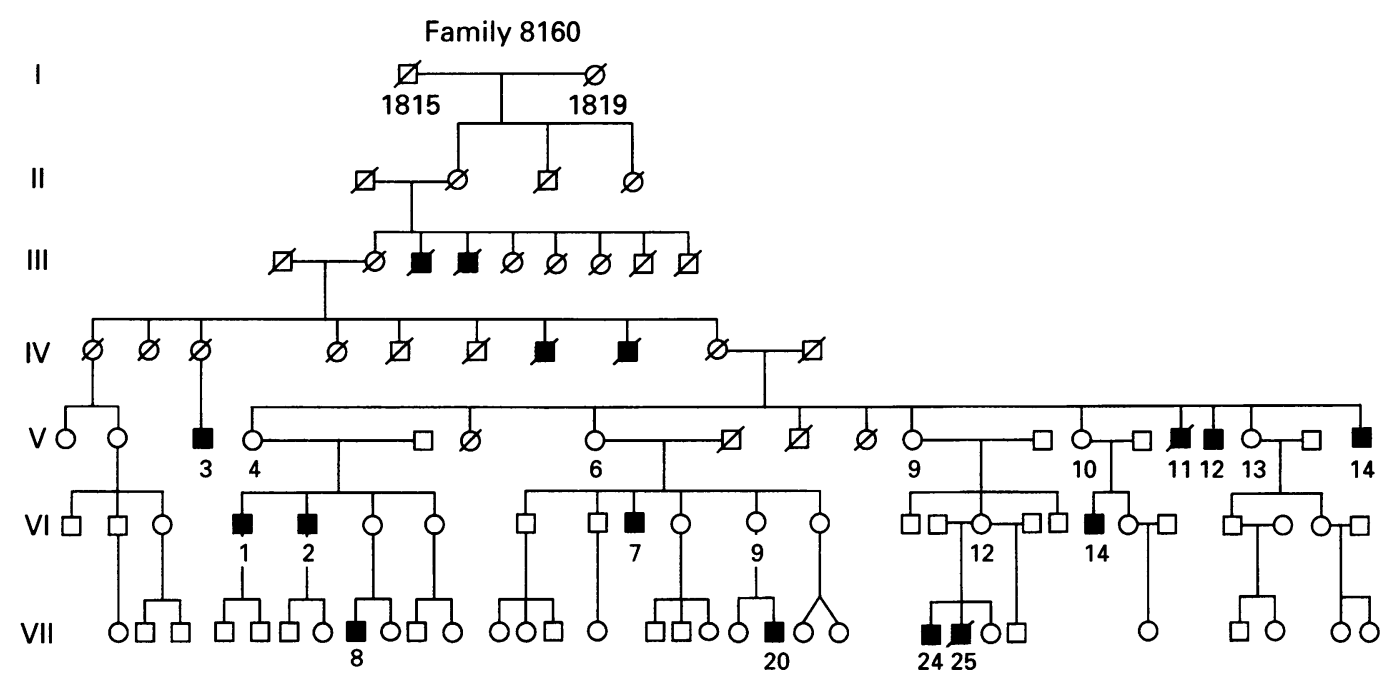

Figure 1 Partial pedigree of family 8160 showing 16 affected males in five generations.

MOLECULAR AND LINKAGE ANALYSIS

Genomic DNA was isolated from blood lymphocytes as previously described ${ }^{7}$ using the "salting out" method. Southern analysis using various $\mathrm{X}$ chromosome markers was carried out as previously described. ${ }^{7-9}$ Probes were labelled by primer extension. ${ }^{10}$ Once linkage was established to probes in Xq21-q22, (CA)n repeat polymorphisms DXS990, ${ }^{11}$ DXS456, ${ }^{12}$ and COL4A $5^{13}$ were used as specified. The amplified products were analysed on $6 \%$ polyacrylamide gels according to previously published protocols. ${ }^{14}$ One trinucleotide repeat, DXS101, ${ }^{15}$ was used incorporating ${ }^{32} \mathrm{P}$ dCTP and polyacrylamide gel electrophoresis. ${ }^{12}$ Two point disease to marker linkage analysis was conducted using MLINK of linkage (V5.1) $)^{16}$ and multipoint analysis was carried out using LINKMAP, ${ }^{17}$ with the mutation rate and gene frequency set at $0.3 \times 10^{-5}$ and 0.0001 respectively.

A mutation in the PLP gene involved in spastic paraplegia ${ }^{18}$ was assayed as follows. Exon 4 of the gene was amplified using primers previously described ${ }^{19}$ in a total volume of $50 \mu \mathrm{l}$. Following amplification, the PCR products were purified by ethanol precipitation and resuspended in $20 \mu \mathrm{l}$ of $\mathrm{H}_{2} \mathrm{O}$. One half of the product was digested with $A c c \mathrm{I}$ according to the supplier's protocol. The digestion products were separated on a $1 \%$ NuSieve GTG agarose gel.

\section{Results}

The pedigree is fully compatible with $\mathrm{X}$ linked recessive inheritance (fig 1 ). At the time of the restudy, 10 affected males were alive. Two (V.11 and VII-25) had died at the age of 59 and 16 , both severely affected by the disorder. There was no medical information on two males (in generation III). Two other males (generation IV) died from tuberculosis at the age of 26 and 28 years. No descendants of the collateral branches of the family have been traced. The main clinical findings are summarised in table 1 .

The unique association of deafness, spasticity, dystonia, ataxia, mental retardation, neuropathy, hip fractures, and progressive visual disability leading to blindness is strikingly similar in all affected, but with considerable variations in severity. The disorder was progressive in all 10 affected males aged 14 to 60 years. Several males had suffered fractures. The type of end stage neurological abnormalities also varied and included spasticity, dystonia, and mental deterioration.

Table 1 Clinical findings in affected males. The four affected males in generations III and IV were known to be deaf, but no information was available on other symptoms. The two affected males in generation IV died from tuberculosis aged 26 and 28 years.

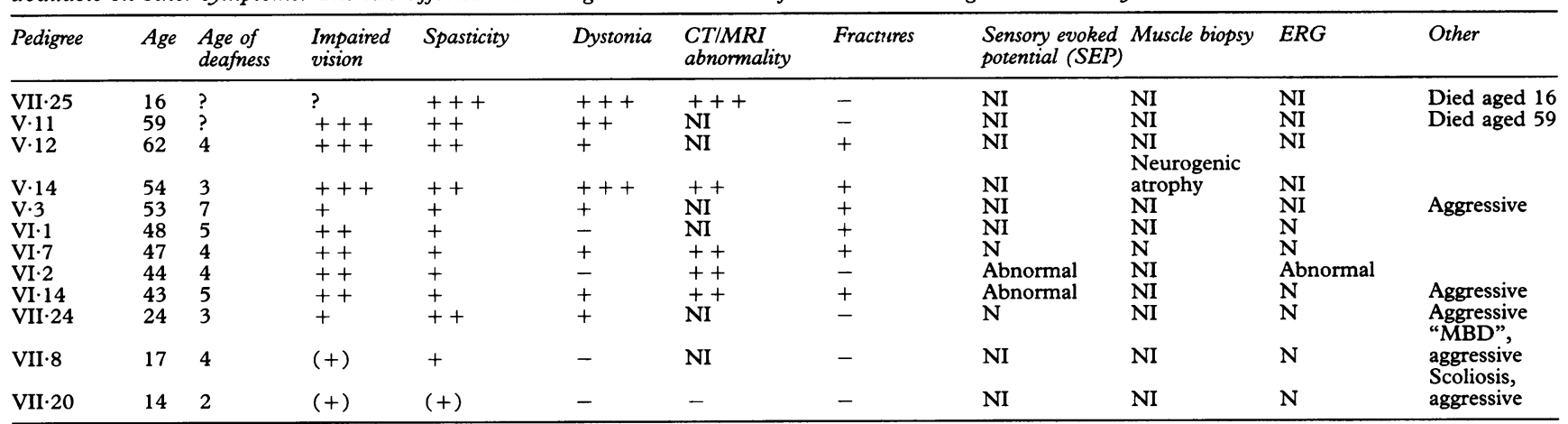

$\mathrm{N}=$ normal, $\mathrm{NI}=$ not investigated, $-=$ not present .

$+=$ mildly affected,$++=$ moderately affected,$+++=$ severely affected. 
A

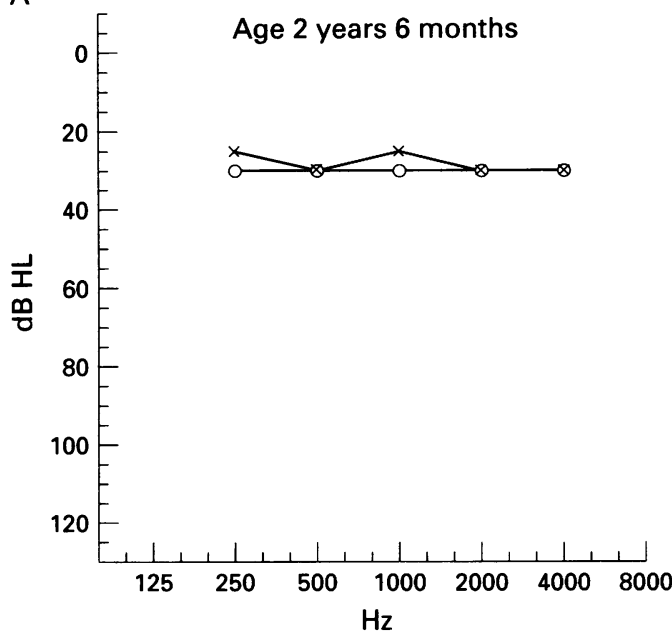

B

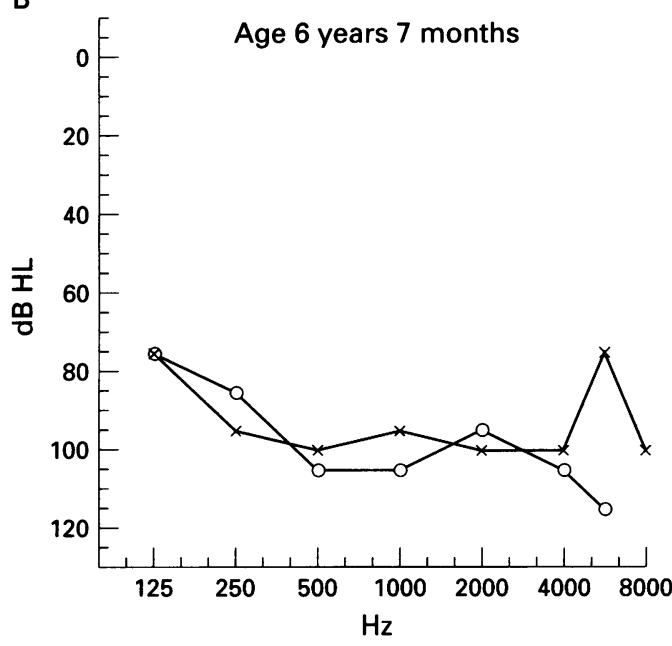

Figure 2 (A) Audiogram from affected male VII $\cdot 8$, aged $3 \frac{1}{2}$ years. (B) Audiogram from $V I I \cdot 8$ aged 6 years 7 months. The audiograms show progression of the hearing loss. Audiograms up to the age of $2 \frac{1}{2}$ years were normal.

\section{CASE REPORT}

$V \cdot 14$

This male was 54 years old when restudied. The main findings are listed in table 1. Cerebral CT scan at the age of 50 showed diffuse central and cortical atrophy which was a typical finding in all affected males older than 40 years.

He had an unremarkable early infancy and developed some speech and hearing which declined rapidly from the age of 3 . At the age of 13 the hearing loss was $>80 \mathrm{~dB}$ and spanned all frequencies tested $(500-4000 \mathrm{~Hz})$. He had to give up his living as a fisherman at 41 years because of severe visual disability. For more than 10 years the visual disability had slowly progressed after a very insidious onset with photophobia. At the age of 49 the visual fields were restricted to $5^{\circ}$ and visual acuity was limited to finger counting. Early in his life there was no indication of colour vision or night vision difficulties. He had a fracture of the femoral neck at 52 years after falling on the ice. There was no evidence of osteoporosis. Physical examination showed normal head circumference, no facial dysmorphic features, and normal testicular size. Histological examination of a muscle biopsy showed neurogenic atrophy. There was no evidence of amyloid deposits.
Urinary and serum metabolic screening, including phytanic acid and very long chain fatty acids, were normal.

$V I I \cdot 25$

He died at the age of 16 and the proposed diagnosis was "dystonia musculorum deformans". No necropsy was performed. This male was the most severely affected with a very early onset of the neurological abnormalities. He was born at term, with normal birth weight, and walked unassisted before 12 months and talked at the normal age. By history and audiological evaluation he had a $40 \mathrm{~dB}$ hearing loss at the age of 7 , and at 11 years the hearing loss was $70 \mathrm{~dB}$. His fine motor skills deteriorated and his gait became ataxic from the age of 7 , and progressed rapidly. A year later he was not able to walk or sit. Thereafter he developed ulnar deviation of both hands, involuntary movements, opisthotonus, and hyperactive deep tendon reflexes. It was not known whether he was blind. His brother (VII.24) also had a more rapidly progressive course than other family members at a comparable age.

\section{HEARING LOSS}

Deafness was the first presenting symptom in all males. Based on family information and information from a deafness registry, a total of 16 males were affected. Hearing impairment was suspected between 18 months and 5 years. Typically, some language was acquired but three males $(\mathrm{V} \cdot 11$, VII.8, and VII.20) never developed intelligible language. Fig $2 \mathrm{~A}$ and $B$ shows audiograms from one affected male, VII $\cdot 8$, and clearly indicates the early but postlingual onset and progressive nature of the hearing loss. CT scan of the temporal bone in VI.7 did not show dilatation of the lateral end of the internal auditory meatus. Vestibular studies, including caloric stimulation, smooth pursuit tracking, and saccadic eye movements, in VI. 7 were normal.

NEUROLOGICAL AND NEUROIMAGING FINDINGS Several males were restless and irritable with anxiety and aggressive outbursts. One male (VII.8) born after an uncomplicated pregnancy and delivery was designated as having "minimal brain dysfunction" even before hearing impairment was evident.

Paranoid symptoms included fear of poisoned food, imaginary visual impressions ("stars seen"), imaginary pulling long hairs out of the eyes, and severe itching without skin abnormalities. The youngest living male examined by cerebral CT scan (VII-20) at the age of 14 had no atrophy or other abnormalities. In five affected males over the age of $40, C T$ scan showed generalised atrophy and no particular cerebellar or basal ganglia pathology. Based on previous studies cerebral atrophy was known to be present exceptionally early in the most severely affected male (VII.25) at the age of 7. Cerebral MRI scan in one male (VI.7) did not show white matter abnormalities. All 
Table 2 DNA markers used for the linkage studies.

\begin{tabular}{|c|c|c|c|c|c|c|c|c|c|c|}
\hline \multirow[t]{2}{*}{ Probe } & \multirow[t]{2}{*}{ Locus } & \multirow[t]{2}{*}{ Location } & \multicolumn{6}{|c|}{ Recombination frequencies $\theta$} & \multirow[t]{2}{*}{$\theta \max$} & \multirow[t]{2}{*}{$Z \max$} \\
\hline & & & $0 \cdot 00$ & 0.01 & 0.05 & $0 \cdot 10$ & $0 \cdot 20$ & $0 \cdot 30$ & & \\
\hline 99.6 & DXS41 & $\mathrm{Xp} 22.1$ & $-4 \cdot 03$ & $-2 \cdot 35$ & $-1 \cdot 05$ & -0.56 & $-0 \cdot 18$ & -0.05 & 0.55 & 0.00 \\
\hline $\mathrm{L} 1.28$ & DXS7 & Xp11.4 & 0.06 & 0.06 & 0.04 & 0.03 & 0.02 & 0.00 & 0.00 & 0.06 \\
\hline $\mathrm{M} 27 \beta$ & DXS255 & $\mathrm{Xp} 11.22$ & -1.57 & $0 \cdot 36$ & $1 \cdot 50$ & $1 \cdot 78$ & 1.68 & 1.25 & $0 \cdot 12$ & 1.80 \\
\hline & DXS1 & $\mathrm{Xq} 12$ & $-0 \cdot 11$ & $-0 \cdot 11$ & $-0 \cdot 11$ & $-0 \cdot 10$ & -0.09 & -0.06 & 0.99 & $0 \cdot 11$ \\
\hline cX37.1 & DXS153 & $\mathrm{Xq} 12$ & $-6 \cdot 62$ & $-3 \cdot 64$ & -1.62 & -0.82 & $-0 \cdot 15$ & 0.87 & 0.37 & $0 \cdot 12$ \\
\hline $\mathrm{RX} 214$ & DXS441 & Xq13-21 & $-1 \cdot 16$ & 0.75 & $1 \cdot 86$ & $2 \cdot 08$ & $1 \cdot 88$ & $1 \cdot 37$ & $0 \cdot 11$ & $2 \cdot 08$ \\
\hline pZ11 & CHM & Xq21.2 & $0 \cdot 11$ & $0 \cdot 11$ & 0.09 & 0.70 & 0.03 & 0.01 & 0.00 & $0 \cdot 11$ \\
\hline pDP34 & DXYS1 & $\mathrm{Xq} 21.3$ & 1.36 & $2 \cdot 28$ & $2 \cdot 72$ & $2 \cdot 68$ & $2 \cdot 22$ & 1.55 & 0.06 & $2 \cdot 73$ \\
\hline p19-2 & DXS3 & Xq21.3 & $-2 \cdot 27$ & $-0 \cdot 28$ & 0.97 & 1.28 & $1 \cdot 34$ & 1.08 & $0 \cdot 16$ & $1 \cdot 37$ \\
\hline AFM136yc7 & DXS990 & Xq21.3 & $2 \cdot 56$ & $3 \cdot 48$ & $3 \cdot 82$ & 3.66 & 2.94 & $2 \cdot 06$ & 0.05 & $3 \cdot 82$ \\
\hline cX52.5 & DXS101 & $\mathrm{Xq} 22$ & $5 \cdot 37$ & $5 \cdot 31$ & $5 \cdot 00$ & $4 \cdot 56$ & 3.52 & $2 \cdot 33$ & 0.00 & $5 \cdot 37$ \\
\hline pXG-12 & DXS94 & $\mathrm{Xq} 22$ & $1 \cdot 16$ & $1 \cdot 12$ & 0.99 & 0.85 & 0.59 & $0 \cdot 38$ & 0.00 & $1 \cdot 16$ \\
\hline S9 & DXS17 & $\mathrm{Xq} 22$ & $4 \cdot 26$ & $4 \cdot 19$ & $3 \cdot 86$ & $3 \cdot 45$ & $2 \cdot 62$ & 1.78 & 0.00 & $4 \cdot 26$ \\
\hline A13.RI & DXS87 & Xq22 & 0.35 & 0.33 & 0.26 & $0 \cdot 18$ & 0.07 & 0.01 & 0.00 & $0 \cdot 35$ \\
\hline XG30B & DXS456 & $\mathrm{Xq} 22$ & $1 \cdot 47$ & $2 \cdot 39$ & $2 \cdot 79$ & 2.69 & $2 \cdot 16$ & 1.44 & 0.05 & $2 \cdot 79$ \\
\hline COL4A5 & COL4A5 & $\mathrm{Xq} 22$ & -0.72 & $0 \cdot 24$ & 0.79 & 0.88 & 0.78 & 0.56 & $0 \cdot 11$ & 0.88 \\
\hline p43-15 & DXS42 & $\mathrm{Xq} 24$ & 1.06 & 1.71 & $2 \cdot 42$ & $2 \cdot 51$ & $2 \cdot 10$ & 1.42 & 0.08 & $2 \cdot 51$ \\
\hline p22-33 & DXS11 & Xq24 & 0.85 & 0.83 & 0.72 & $0 \cdot 61$ & 0.39 & $0 \cdot 23$ & 0.00 & 0.85 \\
\hline $\mathrm{C} 11$ & DXS144E & $\mathrm{Xq} 26$ & $-1 \cdot 81$ & -0.87 & -0.29 & $-0 \cdot 11$ & -0.05 & $0 \cdot 13$ & 0.33 & 0.01 \\
\hline
\end{tabular}

affected males over the age of 54 had dysphagia. In some males there was mild peripheral neuropathy, verified by EMG, neurography, or muscle biopsy. The neurological symptoms and findings represent involvement of basal ganglia, corticospinal tract, and brain stem and indicated a progressive, diffuse, generalised encephalopathy.

VISUAL ABNORMALITIES

The general impression was that photophobia occurred from approximately the age of 15 with

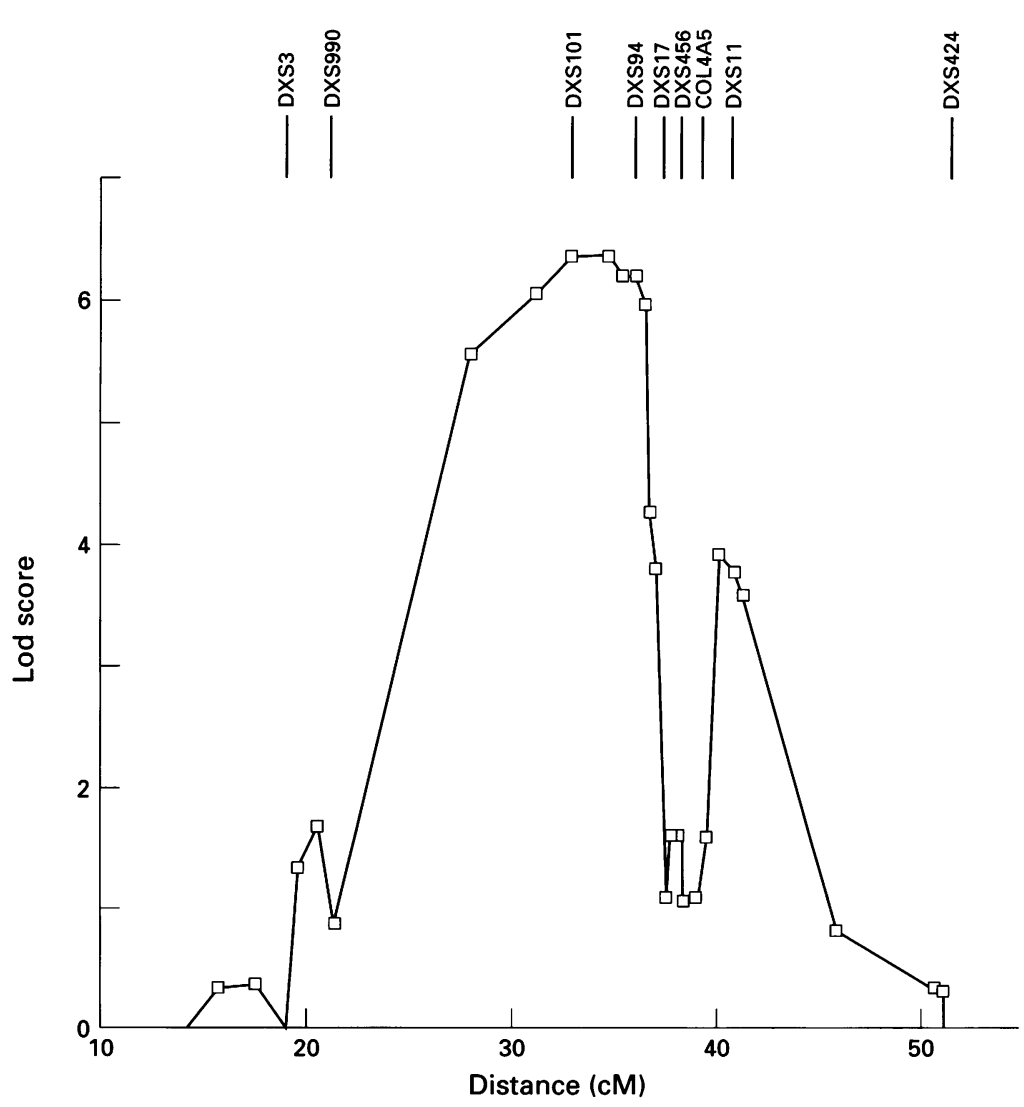

Figure 3 Logarithm of odds of linkage of MTS: multipoint analysis versus map of markers in Xq12-q23. The fixed order and genetic distance were set as follows: DXS153 - 0.03 - DXS441 - 0.06 - DXYS1X - 0.05 - DXS3 - 0.02 - DXS990 - 0.15 DXS94 - 0.01 - DXS17 - 0.01 - DXS456 - 0.01 - COL4A5 - 0.02 - DXS11 $0.05-D X S 42-0.05-D X S 144 E$. Multipoint lod scores correspond to location scores divided by $4 \cdot 6$. preserved colour and night vision. In their midthirties, the males complained of lack of effect of stronger glasses and visual acuity was reduced to $0 \cdot 2(20 / 100)$ or less. Full field electroretinograms in six affected males (VI $1, \mathrm{VI} \cdot 7$, $\mathrm{VI} \cdot 14, \mathrm{VII} \cdot 8, \mathrm{VII} \cdot 20$, VII·24) and two obligate carriers (V.10, VI.9) showed normal retinal function. In these patients the visual abnormalities suggest involvement of the central visual pathways. Ophthalmological examination of VI.2 including electroretinograms showed retinal dysfunction including both rods and cones. Bilateral large central scotomas were also found, and changes in the central retina showed findings compatible with central choroidal areolar dystrophy. ${ }^{20}$ These findings were not observed in other family members.

OTHER STUDIES

The following studies were performed in at least one affected male and were normal: head circumference, electrocardiogram, electroencephalogram, testicular size, serum and spinal pyruvate and lactate, high resolution chromosome RBA banding of cultured peripheral lymphocytes, urinary microscopy, and urinary excretion of monosaccharides. In plasma from at least one affected male we measured very long chain fatty acids, bile acids, phytanic acid, and pristanic acid. The levels of plasmalogens in erythrocytes and peroxisomal enzymes in cultured skin fibroblasts were also normal. Special staining of muscle tissue for amyloidosis was negative. There was no history of infections or other evidence for immune deficiency. None of the affected males had dysmorphic facial features.

Since the original report of this family, ${ }^{6}$ two affected males (VI·1 and VI·2) have reproduced, indicating fertility.

\section{OBLIGATE CARRIERS}

Four obligate female carriers (VI.9, V.4, V.9, $\mathrm{V} \cdot 10)$ had a neurological examination. They were in the age range 42 to 72 years. $V \cdot 4, V \cdot 10$, and $\mathrm{V} \cdot 13$ had mild hearing loss (age range: 57 to 70 years). $\mathrm{V} \cdot 10$ had a $30-45 \mathrm{~dB}$ nonprogressive hearing loss detected at the age of 52 , which was unchanged by the age of 66 . 
$\mathrm{V} \cdot 13 \mathrm{had}$ a $50-70 \mathrm{~dB}$ hearing loss at 57 years. $\mathrm{V} \cdot 4$ had a $70 \mathrm{~dB}$ unilateral hearing loss. The same two obligate carriers $(\mathrm{V} \cdot 4$ and $\mathrm{V} \cdot 10)$ had decreased achilles tendon reflexes and mild reduction of pain and temperature sensation, possibly signs of mild neuropathy. Another obligate female carrier (VI.12) had a normal audiogram at the age of 33 years. No neurological examination was done.

\section{LINKAGE ANALYSIS AND MOLECULAR STUDIES} Linkage analysis was initiated using a collection of Southern based DNA markers, spread along the $\mathrm{X}$ chromosome. Tight linkage was found to the probe DXS17 in Xq22 with a lod score of $4 \cdot 26$ at zero recombination (table 2 ). Available microsatellite markers, in association with Southern based markers clustered in the Xq21q22 region, were then used to refine the localisation of the MTS gene further. Tight linkage was established to DXS101 with a lod score of 5.37 and no recombination. Recombination was observed with DXS990 proximal in Xq21.3 and DXS456 distal in Xq22 (table 2). Multipoint analysis (fig 3 ), using nine markers localised in Xq21.3-q22, located the disease locus near DXS101 with a location score of $6 \cdot 4$ (zero recombination). Using lod-1 support interval to define the limits of localisation, the multipoint analysis places the likely location for the MTS gene within a region spanning from $5 \mathrm{cM}$ proximal to DXS101 to $3 \mathrm{cM}$ distal to this locus. ${ }^{21}$ Kobayashi et $a l^{18}$ recently showed that a family with spastic paraplegia had a point mutation ( $T$ to $C$ ) in exon 4 resulting in a Ile substitution for $T h r$ at residue 186 . This mutation was assayed for in our family by taking advantage of the fact that the $\mathrm{T}$ to $\mathrm{C}$ alteration generates an $A c c I$ site. ${ }^{18}$ All affected males and available carrier mothers were found to be negative for this mutation (data not shown). So far, continuing SSCP analysis of the PLP gene (exons 1, 3, 4, and 6) has not shown any alterations.

\section{Discussion}

The unique combination of deafness, behavioural abnormalities, dystonia, spasticity, ataxia, mental deterioration, visual disability, and fractures suggests a new $\mathrm{X}$ linked recessive syndrome (MTS). Our restudy of this family, initially reported ${ }^{6}$ as non-syndromic deafness, clearly indicates that the disorder is an example of another $\mathrm{X}$ linked deafness syndrome. In addition, we present audiological evidence of early onset of the deafness (fig 2A and 2B). The clinical pattern suggests a progressive neurodegenerative disorder affecting CNS, basal ganglia, corticospinal tract, and possibly the brain stem. The occurrence of hip fractures in many affected males (all $>40$ years) could be secondary to dystonia and ataxic gait since no osteoporosis was found. No biochemical or neuropathological abnormalities have been identified, but the regional mapping to Xq22 points to candidate genes possibly involved. A second DFN-1 family has been reported from South Africa with adolescent onset mild X linked hearing impairment ${ }^{22}$ but no visual or neurological symptoms. No genetic linkage has been reported and the question of allelic disorders or different $\mathrm{X}$ linked mutated gene therefore remains unresolved.

Regional localisation of MTS to Xq22 makes it possible that genes in this region become candidate genes for this disorder. PelizaeusMerzbacher disease (PMD) maps to $\mathrm{Xq}_{22}{ }^{23}$ and is known to result from mutations in the proteolipidprotein gene (PLP). ${ }^{24}$ Clinically, however, deafness and dystonia are not typical in PMD and the progressive loss of vision is accompanied by optic nerve atrophy in PMD. In late stages of PMD, white matter substance shows abnormal signal attenuation on MRI, which was normal in a 47 year old severely affected male in the present family. The recent reports of mutations in the PLP gene leading to a complex $\mathrm{X}$ linked spastic paraplegia ${ }^{1825}$ justify a search for mutations in this gene in the present family. PLP may represent a candidate gene for MTS although one of the spastic paraplegia mutations ${ }^{18}$ was not found to be present in this family.

It seems reasonable to disregard the gene for $\mathrm{X}$ linked agammaglobulinaemia (XLA), which also maps to $\mathrm{Xq} 22,{ }^{2627}$ as a candidate gene, since there was no evidence of immune deficiency. However, there is a report of a patient with XLA, dystonia, and deafness who is deleted for the $3^{\prime}$ end of the XLA gene and a flanking expressed sequence, DXS1274E. ${ }^{28}$ These data do not exclude that a gene near XLA could be involved in the MTS phenotype. No deletions in the PLP gene or the transcribed sequence 5D8 (DXS1274E) or FC12 were detected $^{28}$ (M Bitner-Glindzicz, unpublished data). Other mutations, such as single base pair substitutions, have not been excluded.

The possibility of anticipation is suggested by two brothers (VII.24 and VII-25) who had an earlier onset and more severe course. In contrast to most affected males, VII 25 had significant diffuse cerebral atrophy on CT scan at the age of 7 . The search for the gene will therefore include methods specifically detecting trinucleotide repeats within Xq22.

Alport syndrome (sensorineural deafness, interstitial nephritis, and retinal pathology) is caused by mutations in the COL4A5 gene. The recombination between the present disease gene and a COL4A5 probe combined with lack of kidney disease seems to exclude the COL4A5 gene and maps the syndromic deafness proximal to the COL4A5 gene.

A familial syndrome with dystonia, neural deafness, hyperactivity, and dysarthria ${ }^{29}$ is somewhat similar to the syndrome in the present family. Neuropathology showed neuronal loss and gliosis in the basal ganglia. Unfortunately, the authors have not been able to trace the original family for genetic linkage studies, but the two families may present the same $\mathrm{X}$ linked disorder. $\mathrm{X}$ linked dystonia as an isolated neurological finding has only been described in the Philippines and the gene has been mapped to Xq13.1. ${ }^{30}$ It is therefore unlikely that there should be any relationship to the present syndrome. 
A considerable number of $\mathrm{X}$ linked syndromes with deafness have been mapped to regions other than $\mathrm{Xq} 22{ }^{3}$ These include albinism-deafness syndrome mapping to Xq26.3-q27.1, ${ }^{3}$ Norrie disease mapping to

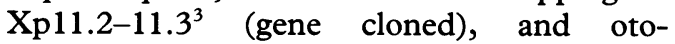
palatodigital syndrome type $\mathrm{I}^{3}$ mapping to $\mathrm{Xq} 28$, as well as the syndrome described by Gustavson et al mapping to $\mathrm{Xq} 26 .{ }^{3132}$ In a family with syndromic $X$ linked deafness ${ }^{33}$ a recent restudy showed linkage to DXS984 in $\mathrm{Xq} 26-\mathrm{q} 27 .{ }^{34}$ Based on the genetic linkage information, they can be disregarded as allelic diseases to the present disease.

There are several purely clinical reports of single families with $\mathrm{X}$ linked deafness in association with various symptoms: high tone deafness, spastic paraparesis, and growth retardation $^{35}$; $\operatorname{ataxia}^{36}$; muscular atrophy, polyneuropathy, and optic atrophy ${ }^{37}$; optic atrophy, muscular atrophy, and neuropathological calcifications ${ }^{38}$; basal ganglia symptoms and microcephaly. ${ }^{39}$ None included genetic linkage studies. The clinical picture was in all cases different from the present family.

Even considering the syndromic pattern of the $\mathrm{X}$ linked deafness in the present family, mapped genes for non-syndromic deafness cannot be totally disregarded because of the possibility of a contiguous gene syndrome.

Previous linkage studies in several families ${ }^{2041}$ have shown genetic heterogeneity in $\mathrm{X}$ linked recessive non-syndromic deafness. The gene responsible for $\mathrm{X}$ linked mixed deafness with perilymphatic gusher and stapedial fixation (DFN-3) is linked to genetic markers in Xq21.1. ${ }^{42-45}$ Further mapping of the region containing the gene has been done by molecular characterisation of deaf patients with microdeletions in that region. ${ }^{44647}$ A gene for severe congenital sensorineural deafness $(\mathrm{DFN}-2)^{48}$ was closely linked to genetic markers in Xq12 in one family. The present classification of non-syndromic $\mathrm{X}$ linked deafness does not show consistency between audiological, neurological, and genetic findings, and needs to be revised. ${ }^{4950}$ The radiological abnormalities with gross dilatation of the internal auditory meatus, for example, have been shown both in DFN-3 ${ }^{51}$ and in DFN-2. ${ }^{48}$ The audiological criteria used previously are, therefore, not reliable in the classification of $\mathrm{X}$ linked non-syndromal deafness. Most recently, another gene for $\mathrm{X}$ linked non-syndromal deafness has been mapped to $\mathrm{Xp} 21.2$ which contains the Duchenne muscular dystrophy gene. ${ }^{52}$

In conclusion, we have restudied a family with $\mathrm{X}$ linked deafness and shown a complex progressive syndromic disorder. ${ }^{53}$ We propose that the syndrome is called Mohr-Tranebjærg syndrome (MTS). As more syndromic and non-syndromic deafness genes are mapped and ultimately cloned, it should be possible to develop a genetically and clinically useful classification. The present family, which represents a new syndrome and has been mapped to Xq22, provides significant new information for this process.
We are indebted to Tobias Gedde-Dahl, Jr, Institute of Forensic Medicine, National Hospital and University of Oslo, who retraced the family; to Margareta Mikkelsen, Department of Medical Genetics, J F Kennedy Institute, DK-Glostrup, who did the high resolution chromosome study; to R B H Schutgens, Department of Pediatrics, Academic Medical Center, Amsterdam, who performed studies of peroxisomal function in blood and fibroblasts; to $\mathrm{J} \mathrm{E}$ Månsson, Department of Clinical blood and fibroblasts; to J E Mansson, Department of Clinical Neuroscience, Section of Neurochemistry, Mölndals Hospital, S-43180 Mölndal, Sweden, who performed urinary monosaccharide measurements; to Egill Hanssen, Department of Ophthalmology, National Hospital, N-Oslo, who did the colou vision tests; to Kjeld Andersen, Department of Neurophysiology, University Hospital, N-Trondheim, who performed the
neurophysiological tests in one affected male; and to Trond neurophysiological tests in one affected male; and to Trond Ganes, Department of Neurophysiology, University Hospital,
Oslo. Maria Bitner-Glindzicz and Marcus Pembrey, Institute of Child Health, London, UK, are kindly thanked for Southern blot analysis for major rearrangements in the transcribed sequence 5D8 (DXS1274E) and FC12 and SSCP analysis. We are especially indebted to the family members who have been extremely cooperative. The study was supported in part by the Norwegian Association for the Blind, the National Institute of Health, grant R01 HD 26202, and by "Forskningsfondet til studier vedrørende tunghørhed og døvhed".

1 Fraser GR. Sex-linked recessive congenital deafness and the excess of males in profound childhood deafness. Am Hum Genet 1965;29:171-91.

2 Reardon W. Genetic deafness. F Med Genet 1992;29:521-6.

3 Duyk G, Gastier JM, Mueller RF. Traces of her workings. Nature Genet 1992;2:5-8.

4 Bach I, Smeets HJM, Brunner HG, et al. Molecular genetics of X-linked deafness. Am $\mathcal{F}$ Hum Genet Suppl 1991;49: A24.

5 Konigsmark BW, Gorlin RJ. Genetic and metabolic deafness. Philadelphia: Saunders, 1976

$6 \mathrm{Mohr}$ J, Magerøy K. Sex-linked deafness of a possibly new type. Acta Genet Stat Med (Basel) 1960;10:54-62.

7 Schwartz CE, Ulmer J, Brown A, Pancoast I, Goodman HO, Stevenson RE. Allan-Herndon syndrome. II. Linkage to DNA markers in Xq21. Am $\mathcal{F}$ Hum Genet 1990;47: 454-8.

8 Schwartz CE, May M, Huang T, et al. MRX8: an X-linked mental retardation condition with linkage to $\mathrm{Xq} 21 . A m \mathcal{F}$ Med Genet 1992;43:467-74.

9 Bialer MG, Lawrence L, Stevenson R, et al. Allan-HerndonDudley syndrome: clinical and linkage studies on a second family. Am $₹$ Med Genet 1992;43:491-7.

10 Feinberg AP, Vogelstein B. A technique for radiolabeling DNA restriction endonuclease fragments to high specific DNA restriction endonuclease fragme
activity. Anal Biochem 1983;132:6-13.

11 Weissenbach J, Gyapay G, Dib C, et al. A second-generation linkage map of the human genome. Nature 1992;359: 794-801.

12 Luty JA, Guo Z, Willard HF, Ledbetter DH, Ledbetter S, Litt M. Five polymorphic microsatellite VNTR's on the human X chromosome. Am $\mathcal{F}$ Hum Genet 1990;46:776-83.

13 Barker DF, Cleverly J, Fain PR. Two CA-dinucleotide polymorphisms at the COL4A5 (Alport syndrome) gene in Xq22. Nucleic Acids Res 1992;20:929.

14 Marinoni JC, Boyd E, Sherman S, Schwartz C. Familial split hand/split foot long bone deficiency does not segregate with markers linked to the SHFD 1 locus in $7 \mathrm{q}$ 21.3-q22.1. Hum Mol Genet 1994;3:1355-7.

15 Allen RC, Belmont JW. Trinucleotide repeat polymorphism at DXS101. Hum Mol Genet 1993;2:1508.

16 Lathrop GM, Lalouel JM. Easy calculations of lod scores and genetic risks on small computers. Am $\mathcal{f}$ Hum Genet 1984;37:460-5.

17 Lathrop GM, Lalouel JM, Julier C, Ott J. Multilocus linkage analysis in humans: detections of linkage and estimation analysis in humans: detections of linkage and estimation
of recombination. Am $₹$ Hum Genet 1986;37:482-98.

18 Kobayashi H, Hoffman EP, Marks HG. The rumpshaker mutation in spastic paraplegia. Nature Genet 1994;7:3512.

19 Strautnieks S, Rutland P, Winter RM, Baraitser M, Malcolm S. Pelizaeus-Merzbacher disease: detection of mutations $\mathrm{Thr}^{181} \rightarrow$ Pro and $\mathrm{Leu}^{223} \rightarrow$ Pro in the proteolipid protein gene, and prenatal diagnosis. Am $\mathcal{F}$ Hum Genet 1992;51: 871-8.

20 Ponjavic V, Andreásson S, Lubs HA, Tranebjærg L. Fullfield electro retinograms in a family with $\mathrm{X}$-linked recessive mental retardation, progressive sensorineural deafness, dystonia, and visual impairment. Ophthalmic Paediatr Genet (in press).

21 Wang LH, Collins A, Lawrence S, Keats BJ, Morton NE. Integration of gene maps: chromosome X. Genomics 1994; 22:590-604

22 Thorpe P, Sellars S, Beighton P. X-linked deafness in a South African kindred. S Afr Med f 1974;48:587-90.

23 Boespflug-Tanguy O, Mimault C, Melki J, et al and the PMD Clinical Group. Genetic homogeneity of PelizaeusMerzbacher disease: tight linkage to the proteolipoprotein locus in 16 affected families. Am $\mathcal{F}$ Hum Genet 1994;55:
461-7.

24 Willard HF, Riordan JR. Assignment of the gene for myelin proteolipid protein to the X-chromosome: implications for X-linked myelin disorders. Science 1985;230:940-2.

25 Saugier-Veber P, Munnich A, Bonneau D, et al. X-linked spastic paraplegia and Pelizaeus-Merzbacher disease are allelic disorders at the proteolipid protein locus. Nature Genet 1994;6:257-62.

26 Vetrie D, Vorechovsky I, Sideras P, et al. The gene involved 
in X-linked agammaglobulinaemia is a member of the $s r c$ family of protein-tyrosine kinases. Nature 1993;361: 226-33.

27 Parolini O, Hejtmancik JF, Allen RC, et al. Linkage analysis and physical mapping near the gene for X-linked agammaglobulinemia at Xq22. Genomics 1993;15:342-9.

28 Vorechovský I, Vetrie D, Holland J, et al. Isolation of cosmid and $\mathrm{CDNA}$ clones in the region surrounding the $B T K$ gene at Xq21.3-q22. Genomics 1994;21:517-24.

29 Scribanu N, Kennedy C. Familial syndrome with dystonia, neural deafness, and possible intellectual impairment: clinical course and pathological findings. Adv Neurol (Dyical course and pathologic
stonia) $1975 ; 14: 235-43$.

30 Muller U, Haberhausen G, Wagner T, Fairweather ND, Chelly J, Monaco AP. DXS106 and DXS559 flank the Chelly J, Monaco AP. DXS106 and DXS559 flank the
X-linked dystonia-parkinsonism syndrome locus DYT3. X-linked dystonia-parkinso

31 Gustavson K-H, Anneren G, Malmgren H, Dahl N, Ljunggren CG, Backman $H$. New X-linked syndrome with severe mental retardation, severely impaired vision, severe hearing defect, epileptic seizures, spasticity, restricted join mobility and early death. Am F Med Genet 1993;45:654-8.

32 Malmgren $\mathrm{H}$, Sundvall $\mathrm{M}$, Dahl $\mathrm{N}$, et al. Linkage mapping of a severe X-linked mental retardation syndrome. $A m \Im$ Hum Genet 1993;52:1046-52.

33 Cowchock FS, Duckett SW, Streletz LJ, Graziani LJ, Jackson LG. X-linked motor-sensory neuropathy type-II with deafness and mental retardation: a new disorder. $A m 7 \mathrm{Med}$ Genet 1985;20:307-15.

34 Priest JM, Fischbeck KH, Nouri N, Keats BJB. A locus for axonal motor-sensory neuropathy with deafness and mental retardation maps to Xq26-q27. Am f Hum Genet 1994;55:200A.

35 Wells CR, Jankovic J. Familial spastic paraparesis and deafness. A new X-linked neurodegenerative disorder. Arch ness. A new X-linked

36 Schmidley JW, Levinsohn MW, Manetto V. Infantile Xlinked ataxia and deafness: a new clinicopathologic entity? Neurology 1987;37:1344-9.

37 Rosenberg RN, Chutorian A. Familial opticoacoustic nerve degeneration and polyneuropathy. Neurology 1967;17: 827-32.

38 Jensen PKA. Nerve deafness, optic nerve atrophy, and dementia: a new $\mathrm{X}$-linked recessive syndrome? $\mathrm{Am} \mathcal{f} \mathrm{Med}$ Genet 1981;9:55-60.

39 Schimke RN, Horton WA, Collins DL, Therou L. A new $\mathrm{X}$-linked syndrome comprising progressive basal ganglion dysfunction, mental and growth retardation, external ophthalmoplegia, postnatal microcephaly and deafness. $A m \mathcal{F}$ Med Genet 1984;17:323-32.
40 Reardon W, Middleton-Price HR, Sandkuijl L, et al. A multipedigree linkage study of $\mathrm{X}$-linked deafness: linkage to Xq13-q21 and evidence for genetic heterogeneity. Genomics 1991;11:885-94.

41 Reardon W, Roberts S, Phelps PD, et al. Phenotypic evidence for a common pathogenesis in X-linked deafness and in Xq13-q21 deletion related deafness. Am f Med Genet 1992;44:513-7.

42 Wallis C, Ballo R, Wallis G, Beighton P, Goldblatt J. Xlinked mixed deafness with stapes fixation in a Mauritian 299-301.

43 Bach I, Robinson D, Thomas N, Ropers HH, Cremers FPM. Physical fine mapping of genes underlying $\mathrm{X}$-linked FPM. Physical fine mapping of genes underlying X-linked Xq21. Hum Genet 1992;89:620-4.

44 Bach I, Brunner HG, Beighton P, et al. Microdeletions in patients with Gusher-associated, X-linked mixed deafness. Am f Hum Genet 1992;50:38-44.

45 Brunner HG, van Bennekom C, Lambermon EMM, et al. The gene for $\mathrm{X}$-linked progressive mixed deafness with perilymhatic gusher during stapes surgery (DFN3) is linked to PGK. Hum Genet 1988;80:337-40

46 Brunner HG, Smeets B, Smeets D, et al. Molecular genetics of X-linked hearing impairment. Ann N Y Acad Sci 1991; 630: $176-90$.

47 Huber I, Bitner-Glindzicz M, de Kok YJM, et al. X-linked mixed deafness (DFN-3): cloning and characterization of the critical region allows the identification of novel microdeletions. Hum Mol Genet 1994;3:1151-4.

48 Robinson D, Lamont M, Curtis G, Shields DC, Phelps P. A family with X-linked deafness showing linkage to the proximal $\mathrm{Xq}$ region of the $\mathrm{X}$ chromosome. Hum Genet proximal Xq

49 Reardon W, Middleton-Price H, Malcolm S, Phelps P, Pembrey ME. X-linked deafness is a heterogeneous disorder F Med Gemet 1990;27:646A.

50 Reardon W, Middleton-Price HR, Malcolm S, et al. Clinical and genetic heterogeneity in X-linked deafness. Brf Audio$\log 1992 ; 26: 109-14$

51 Phelps PD, Reardon W, Pembrey M, Bellman S, Luxon L. $\mathrm{X}$-linked deafness, stapes gushers and a distinctive defect of the inner ear. Neuroradiology 1991;33:326-30.

52 Lalwani AK, Brister JR, Fex J, et al. A new nonsyndromic Xlinked sensorineural hearing impairment linked to Xp21.2. Am f Hum Genet 1994;55:685-94.

53 Tranebjærg L, Schwartz C, Huggins K, et al. X-linked recessive mental retardation with progressive sensorineural deafness, blindness, spastic paraplegia and dystonia. $\mathrm{Am}$ f Hum Genet 1992;51:47A. 